\title{
The studies of the dynamic and material parameters of reinforced concrete elements with the addition of zeolite tuffs and plasticizer
}

\author{
Jacek Szulej \\ Department of Structural Mechanics, Faculty of Civil Engineering and Architecture, \\ Lublin University of Technology, e-mail: j.szulej@pollub.pl
}

\begin{abstract}
The aim of article is to present the analysis results of damping parameters of vibrations as well as material features of reinforced concrete structures with the addition of zeolite tuffs and plasticizer. The first part describes the properties of zeolite and the impact of its addition on concrete parameters. The main part demonstrates the results of analysis on damping parameters of vibrations of reinforced concrete plate models. They contain a modified binder in which the part of cement was replaced by zeolite. The values of damping parameters were determined by the collocation method and only the first frequency of models free vibrations was taken into account. Moreover, the material characteristics of modified concrete were also determined, such as, compression strength, measured after 3, 7, 14, 28 days, frost resistance, penetration depth of water under pressure, abrasion, and the value of Young's modulus as well as Poisson's ratio.
\end{abstract}

Keywords: damping parameter of vibrations, material characteristics, zeolite, clinoptilolite, concrete.

\section{Introduction}

The continuous development of structures of considerable spans and little stiffness requires searching for new or modifying already known materials of better dynamic properties and material parameters. Bearing this fact in mind, it was decided to recognize dynamic and material characteristics of modified concrete. Modification consists in replacing one part of cement by zeolite, thus by a relatively new component of concrete mixture. In order to improve workability of concrete mixture containing zeolite, plasticizer was used.

Strength and material parameters of concretes with the addition of different types of zeolite, occurring at various regions of world, were partially recognized, however, the studies on zeolite tuffs coming from the deposits located in Ukraine are still missing. The tests referring to the estimation of damping level of structure elements with the addition of zeolite have not been performed yet.

Reinforced concrete plate models were used to the analysis on the level of vibration damping. The tests consisted in exciting vibrations of mentioned models and determining damping quantity of vibrations on the basis of time course analyses of vibrations (collocation method).

The first mode of free vibrations of models was taken into account. The identification of dynamic parameters was conducted using MES Algor program. In the calculations, only the scope of small free vibrations was considered. Standard cubic and cylindrical samples were used to examine material characteristics. 


\section{Initial information on properties and application of zeolite}

Zeolites are the group of aluminosilicate of unique physic and chemical properties. Due to this fact they have numerous practical applications. These properties mainly result from their specific internal structure. In a spatial, aluminosilicate skeleton, there are free spaces in the form of cells and channels of specifically determined molecular dimensions. While adding chemical resilience and high thermostability, very good catalytic properties, sorption-ion exchange and molecular-screen properties, thus it is not surprising that zeolites are an extremely significant material having numerous applications to chemical technologies, engineering and environmental protection, agriculture and construction [1-6].

Despite the fact that in nature, there are 100 varieties of zeolite minerals of different type, accumulation deposits are very few. Most widespread zeolite mineral and at the same time most commonly applied is clinoptilolite. It crystallizes in the monoclinic crystal system of spatial group $\mathrm{C} 2 / \mathrm{m}$ and a primitive cell: $a=1,766 \mathrm{~nm}, b=1,726 \mathrm{~nm}, c=0,720 \mathrm{~nm}$, $\beta=116,4^{\circ}$. The most commonly provided, crystallographic formula for clinoptilolite assumes the form: $\left(\mathrm{K}_{2}, \mathrm{Na}_{2}, \mathrm{Ca}\right)_{3}\left[\mathrm{Al}_{6} \mathrm{Si}_{30} \mathrm{O}_{72}\right] \cdot 24 \mathrm{H}_{2} \mathrm{O}$.

Natural zeolites, and especially clinoptilolite, by reacting with $\mathrm{Ca}(\mathrm{OH})_{2}$ are capable of creating typical gel products of hydration (C-S-H, C-A-H). The content of $\mathrm{Ca}(\mathrm{OH})_{2}$ in the hydration products is decreasing substantially, which is due to the greater chemical resistance and lower porosity of systems with cement containing clinoptilolite. For this reason, this mineral is a precious natural pozzolanic additive to produce concrete.

The tests results of concrete samples with the addition of zeolite [7-10] confirm considerable efficiency of natural zeolite positively acting on, among others, water penetration, degree of corrosion and concrete shrinkage, increase of strength and durability, corrosion resistance.

\section{Description of zeolite properties applied to tests}

In the analysis of zeolite impact on dynamic and material features of modified concrete, clinoptilolite coming from the deposits of zeolite tuffs in Sokyrnytsya (Zakarpatia Oblast, Ukraine) was applied. A diffractogram of mineral content of this rock are shown in Fig. 1. A dominant component is clinoptilolite, recognized by characteristic and stronger reflexes $d_{h k l}=8,95 ; 7,94 ; 3,96 ; 3,90 \AA$. Its quantitative content is about $75 \%$. Mineral contents of tuff are complimented by minor amounts of opal CT, quartz and potassium feldspar.

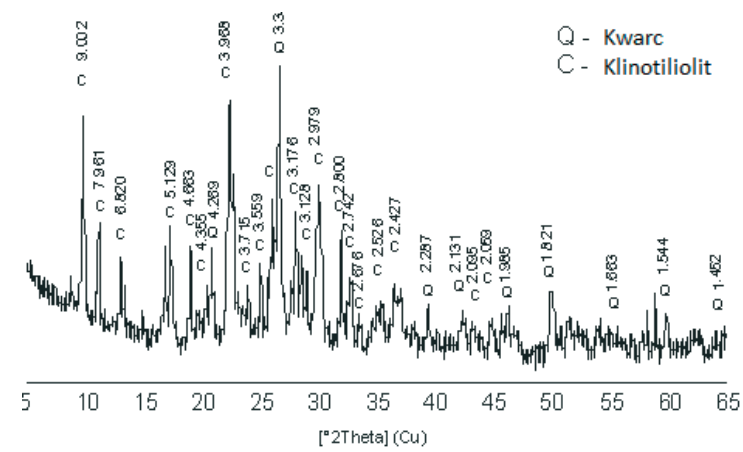

Fig. 1. Diffractogram of mineral content of zeolite tuffs 
Clinoptilolite occurs in the form of thin plates of dimensions $25-30 \mu \mathrm{m}$ which sometimes have got a hexagonal cross-section (Fig. 2).

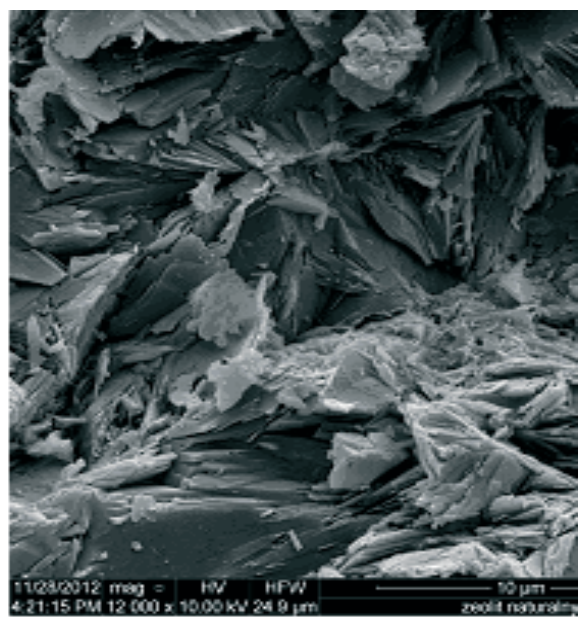

Fig. 2. Microphotograph of clinoptilolite grains concentration

In the chemical content there are: $\mathrm{SiO}_{2} 68,02 \%$ and $\mathrm{Al}_{2} \mathrm{O}_{3} 12,92 \%$ creating the frame of clinoptilolite structure which are accompanied by $\mathrm{CaO} 3,71 \% ; \mathrm{K}_{2} \mathrm{O} 3,36 \% ; \mathrm{MgO} 0,75 \%$ $\mathrm{Na}_{2} \mathrm{O} 0,69 \%$ - playing the role of ion exchange cations compensating for the charge excess of frame. The selected zeolite material is characterized by the value of specific surface which in the case of clinoptilolite is $18,3 \mathrm{~m}^{2} / \mathrm{g}$ (about 50 times greater than specific surface of cement). Due to the fact that the deciding content in developed surface has a mesoporous material $10,65 \mathrm{~m}^{2} / \mathrm{g}$, in relation to a microporous material whose surface is $7,68 \mathrm{~m}^{2} / \mathrm{g}$, this material texturally represents the mesoporous material.

\section{Description of tests on models and samples}

Five series of concrete samples were made, including cubic samples $(15 \mathrm{~cm} \mathrm{x} 15 \mathrm{~cm} \mathrm{x}$ $15 \mathrm{~cm})$ and cylindrical ones $(\mathrm{d}=15 \mathrm{~cm}, \mathrm{~h}=30 \mathrm{~cm})$ which contain the same amounts of aggregate, water and plasticizer, however, they differ in the amount of cement and zeolite (they contain $0 \%, 10 \%, 20 \%, 30 \%, 40 \%$ of zeolite instead of cement).

Detailed data on materials referring to the series of samples as well as the mass of particular components in $1 \mathrm{~m}^{3}$ of concrete mix are presented in Tab. 1.

Table 1. Compilation of material data concerning performed series of samples and models as well as the mass of particular components falling to $1 \mathrm{~m}^{3}$ of concrete mix.

\begin{tabular}{lccccc}
\hline Marking of samples and models series & A_0 & B_10 & C_20 & D_30 & E_40 \\
\hline Cement I 32.5 $\left(\mathrm{kg} / \mathrm{m}^{3}\right)$ & 281 & 252,9 & 224,8 & 196,6 & 168,6 \\
\hline Zeolite $\left(\mathrm{kg} / \mathrm{m}^{3}\right)$ & 0 & 28,1 & 56,2 & 84,4 & 112,4 \\
\hline Plasticizer Betostat, $0,5 \%$ of cement mass $\left(\mathrm{kg} / \mathrm{m}^{3}\right)$ & 1,4 & 1,4 & 1,4 & 1,4 & 1,4 \\
\hline Natural pebble aggregate, $2-8 \mathrm{~mm}\left(\mathrm{~kg} / \mathrm{m}^{3}\right)$ & 1240 & 1240 & 1240 & 1240 & 1240 \\
\hline Sand, $1-2 \mathrm{~mm}\left(\mathrm{~kg} / \mathrm{m}^{3}\right)$ & 477 & 477 & 477 & 477 & 477 \\
\hline Water $\left(\mathrm{kg} / \mathrm{m}^{3}\right)$ & 138 & 138 & 138 & 138 & 138 \\
\hline
\end{tabular}


Furthermore, five plate models were performed, differing in the content of concrete mix, as it is shown in Tab. 1. Every model consists of plate of thickness $6 \mathrm{~cm}$, of dimensions $2 \mathrm{~m} \times 1 \mathrm{~m}$, pinned supported in four points and it has got bottom structural reinforcement in the form of ribbed bars net of cross-section 6mm (Fig. 3).

In order to obtain material characteristics of modified concrete, research on concrete samples was carried out and on the basis of these studies, the compression strength of concrete, Young's modules and Poisson's ratios were obtained. Using these values of material constants, the natural frequencies of plate models were calculated (using Algor program).

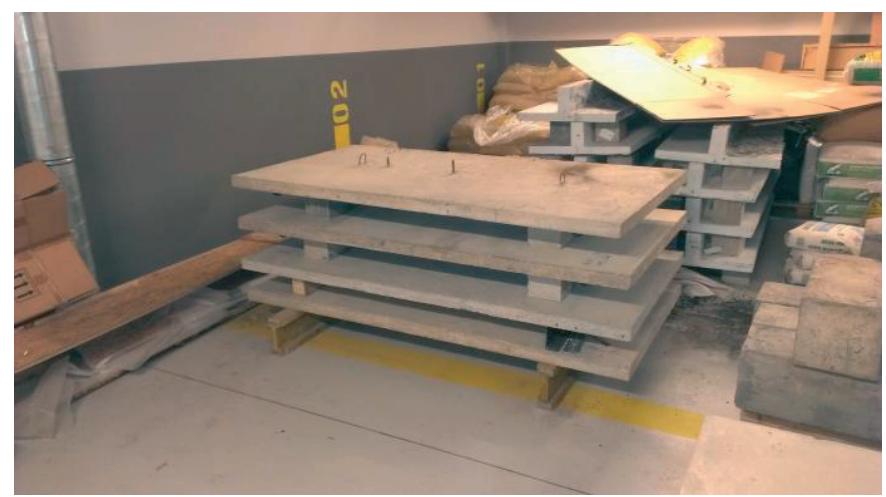

Fig. 3. Plate models used in tests

The damping level of models vibrations is determined by applying the collocation method, described in works $[11,13]$. The collocation method requires conducting the measurements of free vibrations of models. In order to do this, the research with the use of HBM equipment was performed: accelerometers B200, analyzer Spider, and control program Catman 5.0. At every model, two accelerometers were fixed (in $1 / 2$ and 1/4 of span). The measurements of accelerations from excitations were conducted at three places. The location of sensors and the places of vibration excitation are demonstrated in Fig. 4.

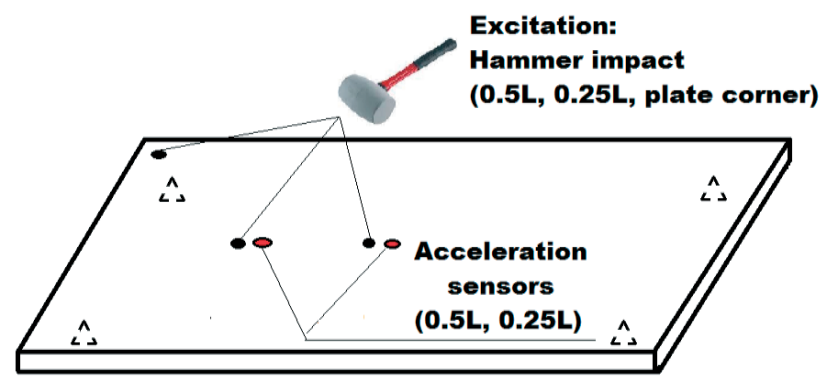

Fig. 4. The distribution of accelerations sensors and places in which vibrations were excited

The results of measurements are accelerations of vibrations in time, sampled with the frequency of $1200 \mathrm{~Hz}$ and band of $150 \mathrm{~Hz}$ for every from five models. On the basis of time courses, a spectral analysis of vibrations was performed by Catman 5.0 program, FFT: Auto Power Spectrum - Amplitude.

Figure no. 5 shows a sample time course of vibrations acceleration, and Figure no. 6 presents sample spectral amplitude. 


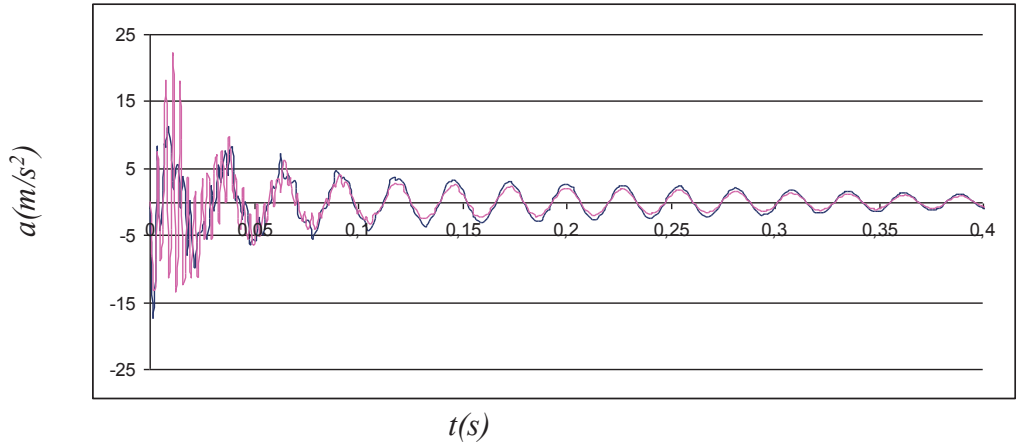

Fig. 5. Sample time course of vibrations (model with $10 \%$ content of zeolite, excitation in point 1 , sensor no. 1 and 2)



Fig. 6. Sample amplitude spectrum of vibrations accelerations (model with $10 \%$ content of zeolite, excitation in point 1 , sensor no. 1 and 2). Frequencies of free vibrations obtained from research were verified by the calculations in Algor program (MES program). The yielded values of natural frequencies were similar. Tab. 2 shows obtained frequencies

Table 2. Compilation of natural frequencies of plate models obtained in the research and Algor program

\begin{tabular}{lccccc}
\hline Marking of plate models & A_0 & B_10 & C_20 & D_30 & E_40 \\
\hline First natural frequencies (research) $\mathrm{Hz}$ & 36,29 & 37,22 & 35,48 & 31,52 & 26,52 \\
\hline First natural frequencies (Algor) $\mathrm{Hz}$ & 35,06 & 35,38 & 34,67 & 31,66 & 29,24 \\
\hline
\end{tabular}

The first mode of free vibrations referring to the model A_0, which was obtained in Algor program, is shown in Fig. 7.

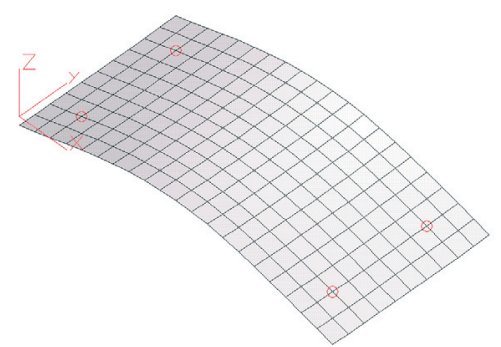

Fig. 7. The first mode of free vibrations of plate models 


\section{Selected parameters of material concrete samples}

The result of analysis on material characteristics were, among others, the values of Young's modules, Poisson's ratios, compressive strength, penetration depth of water under pressure of concrete samples corresponding to particular plate models. The results are listed in Tab. 3 .

Table 3. Values of Young's modules, Poisson's ratios, penetration depth of water under pressure of concrete samples

\begin{tabular}{ccccc}
\hline $\begin{array}{c}\text { Markings } \\
\text { of samples series }\end{array}$ & $\begin{array}{c}\text { Young's } \\
\text { modulus }\end{array}$ & $\begin{array}{c}\text { Poisson's } \\
\text { ratio }\end{array}$ & $\begin{array}{c}\text { 28-day } \\
\text { compressive strength }\end{array}$ & $\begin{array}{c}\text { Penetration depth } \\
\text { of water under pressure }\end{array}$ \\
\hline A $[\mathrm{GPa}]$ & {$[-]$} & {$[\mathrm{MPa}]$} & {$[\mathrm{cm}]$} \\
\hline B_10 & 26,06 & 0,164 & 26,96 & 2,77 \\
\hline C_20 & 26,52 & 0,183 & 32,52 & 2,48 \\
\hline D_30 & 25,45 & 0,186 & 28,37 & 3,75 \\
\hline E_40 & 21,23 & 0,182 & 25,81 & 3,30 \\
\hline
\end{tabular}

\section{Parameters of vibrations damping}

The values of logarithmic decrement of damping of vibrations first modes were estimated on the basis of collocation method $[11,12]$. In the collocation method, a damping parameter is obtained, referring to the form of vibrations, even in the case of not separated natural frequencies. Fig. 5 demonstrates average values of logarithmic decrement of vibrations damping of plate models, taking into account data from an acceleration sensor no. 1, 2 and excitation at the mid-length of plate models.

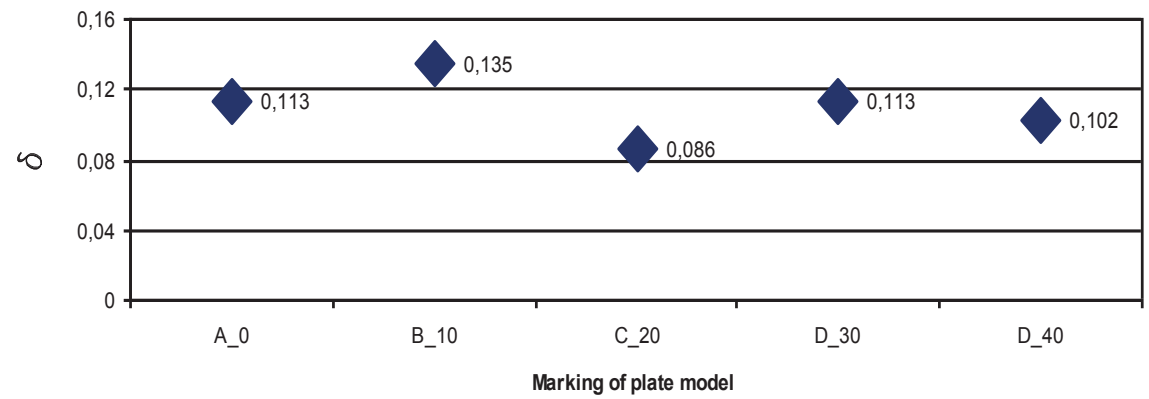

Fig. 8. The average values of logarithmic decrement of vibrations damping referring to the first mode of natural vibrations of plate models.

As a result of conducted research, the highest damping level was obtained referring to the model with $10 \%$ content of zeolite, whereas the level of vibrations damping of subsequent models demonstrates decreasing values.

In order to compare obtained results with data available in literature, the values of damping of material reinforced concrete, wood and steel acc. to [12] are listed in Tab. 4. 
Table 4. Values $\delta$ of selected materials

\begin{tabular}{lc}
\hline \multicolumn{1}{c}{ Material } & Average value $\delta$ \\
\hline Reinforced concrete poorly prestressed (uncracked) & 0,054 \\
\hline Reinforced concrete medium prestressed (cracked) & 0,157 \\
\hline Reinforced concrete strongly prestressed (cracked) & 0,141 \\
\hline Wood & 0,079 \\
\hline Steel & 0,010 \\
\hline
\end{tabular}

Comparing obtained results of logarithmic decrement of vibrations damping from research and data from literature, it shall be stated that adding zeolite enables obtaining the damping level of vibrations within the scope of poorly to medium prestressed concrete.

\section{Summary}

While determining a damping level, only the first modes of free vibrations of models were taken into account (collocation method), these are the first flexural symmetrical forms of vibrations. Considering the results obtained using the collocation method, the increase of damping level of model containing $10 \%$ of zeolite additive, can be observed, whereas, subsequent models show a decreasing trend. All the results oscillate within the range concerning poorly and medium prestressed reinforced concrete.

The research on material parameters demonstrates similar values of Young's modulus in the models without zeolite and models with $10 \%$ and $20 \%$ of zeolite in a concrete mix, however, the maximum value of this parameter is reached by the model with $10 \%$ content of zeolite (B_10). The drop in value E can be observed in the model D_30, and the lowest value in the model E_40. Poisson's ratios of models with $10-30 \%$ content of zeolite have very similar values.

\section{Acknowledgement}

Research was financed within the frames of project No. IPBU.01.01.00-06-570/11-00.

\section{References}

1 Wdowin M., Franus M., Panek R, Bandura L, Franus W. The conversion technology of fly ash into zeolites. Clean Technologies and Environmental Policy, DOI 10.1007/s10098-014-0719-6 (2014).

2 Chałupnik S., Franus W., Wysocka M., Gzyl G. Application of zeolites for radium removal from mine water. Environmental Science and Pollution Research 20 (2013) 7900-7906.

3 Wdowin M., Franus W, Panek R. Preliminary results of usage possibilities of carbonate and zeolitic sorbents in CO2 capture. Fresenius Environmental Bulletin 21(12) (2012) 3726 -3734.

4 Franus W. Characterization of X-type zeolite prepared from coal fly ash. Polish Journal of Environmental Studies 21(2) (2012) 337-343.

5 Franus W, Wdowin M. Removal of ammonium ions by selected natural and synthetic zeolites. Mineral Resources Management 26(4) (2010) 133-148.

6 Franus W, Dudek K. Clay minerals and clinoptilolite of Variegated Shales Formation of the Skole Unit. Polish Flysch Carpathians. Geologica Carpathica 50 (1999) 23-24. 
7 Meysam N., et al. An experimental study on durability properties of ceoncere containing zeolite as a highly reactive natural pozzolan. Construction and Building Materials 35 (2012) 1023-1033.

8 Ahmadi B., Shekarch M. Use of natural zeolite as a supplementary cementitiuos material. Cement \& Concrete Composites 32 (2010) 134-141.

9 Y1lmaz B., et al. Properties of zeolitic tuff (clinoptilolite) blended portland cement. Building and Environment 42 (2007) 3808-3815.

10 Bilim C. Properties of cement mortars containing clinoptilolite as a supplementary cementitious material. Construction and Building Materials 25 (2011) 3175-3180.

11 Flaga A., Szulej J. Metoda wyznaczania współczynników tłumienia drgań konstrukcji zespolonych. Konferencja Naukowa, Krynica (2005) 49-54.

12 Bachmann H. et al. Vibration problems in structures. Practlical Guidelines. Wien, Bulletin D’Information, No 209, Lausanne, 1991.

13 Flaga A., Szulej J. Metoda kolokacyjna wyznaczania parametrów tlumienia drgań w konstrukcjach budowlanych. Konferencja Naukowa Dynkon 2008, Rzeszów-Bystre (2008) 6572 .

\title{
Badania parametrów \\ dynamicznych i materiałowych elementów żelbetowych z dodatkiem zeolitu i plastyfikatora
}

\author{
Jacek Szulej \\ Katedra Mechaniki Budowli, Wydziat Budownictwa i Architektury, Politechnika Lubelska, \\ e-mail:j.szulej@pollub.pl
}

Streszczenie: Celem artykułu jest przedstawienie wyników badań parametrów tłumienia drgań oraz cech materiałowych konstrukcji żelbetowych z dodatkiem tufów zeolitowych i plastyfikatora. Część pierwsza artykułu opisuje właściwości zeolitów oraz wpływ jego dodatku na parametry betonu. Część główna artykułu przedstawia wyniki badań parametrów tłumienia drgań żelbetowych modeli płytowych. Modele posiadają zmodyfikowane spoiwo, w którym część cementu zastąpiono zeolitem. Wartości współczynników tłumienia drgań określano metodą kolokacyjną i uwzględniano tylko pierwszą częstość drgań własnych modeli. Zestawiono również wartości charakterystyk materiałowych zmodyfikowanego betonu takie jak moduły Younga i wartości współczynników Poissona.

Słowa kluczowe: parametr thumienia drgań, cechy materiałowe, zeolit, klinoptylolit, beton. 